\title{
Brexpiprazole Reduces Survivin and Reverses EGFR Tyrosine Kinase Inhibitor Resistance in Lung and Pancreatic Cancer
}

\author{
TOMOMI SANOMACHI ${ }^{1,2^{*}}$, SHUHEI SUZUKI ${ }^{1,2^{*}}$, KEITA TOGASHI $^{1,3}$, SHIZUKA SEINO $^{1}$, \\ TAKASHI YOSHIOKA ${ }^{2}$, CHIFUMI KITANAKA ${ }^{1,4}$, MASASHI OKADA $^{1}$ and MASAHIRO YAMAMOTO ${ }^{1}$ \\ ${ }^{1}$ Department of Molecular Cancer Science, Yamagata University School of Medicine, Yamagata, Japan; \\ ${ }^{2}$ Department of Clinical Oncology, Yamagata University School of Medicine, Yamagata, Japan; \\ ${ }^{3}$ Department of Ophthalmology and Visual Sciences, Yamagata University School of Medicine, Yamagata, Japan; \\ ${ }^{4}$ Research Institute for Promotion of Medical Sciences, Yamagata University Faculty of Medicine, Yamagata, Japan
}

\begin{abstract}
Background/Aim: Although epidermal growth factor receptor (EGFR) is frequently activated in lung and pancreatic cancers, the efficacy of EGFR tyrosine kinase inhibitors (EGFR-TKIs) is limited. Recently, brexpiprazole, an antipsychotic drug, was reported to chemosensitize glioma cells to osimertinib, a third-generation EGFR-TKI, by suppressing survivin, an anti-apoptotic protein, but their combinational effects on lung and pancreatic cancers remain unknown. The aim of this study was to examine the combinational effects of brexpiprazole and osimertinib on lung and pancreatic cancer cells in vitro and in vivo. Materials and Methods: YM155, a suppressor of survivin, siRNA, and immunoblot were used to examine the role of survivin in osimertinib-resistance. The effect of drugs on cell viability in vitro was examined by trypan blue staining. The in vivo effects of drugs on tumor growth were examined using a xenograft mouse model. Results: Brexpiprazole exerted combinational effects with osimertinib in vitro. Pharmacological and genetic suppression of survivin chemosensitized the cells to osimertinib. Moreover, the combination of brexpiprazole and osimertinib effectively suppressed tumor growth in a mouse xenograft model. Conclusion: Brexpiprazole is a promising drug for lung and pancreatic cancer in combination with osimertinib.
\end{abstract}

The epidermal growth factor receptor (EGFR) pathway is activated by gene mutation, gene amplification, or both in

*These Authors contributed equally to this work.

Correspondence to: Masahiro Yamamoto, Department of Molecular Cancer Science, Yamagata University School of Medicine, 2-2-2 Iida-nishi, Yamagata 990-9585, Japan. Tel: +81 236285214, Fax: +81 236255215, e-mail: masahiro@med.id.yamagata-u.ac.jp

Key Words: Brexpiprazole, osimertinib, non-small cell lung cancer, pancreatic cancer, survivin. several types of cancer, including non-small-cell lung cancer (NSCLC), pancreatic cancer, glioblastoma, colorectal cancer, breast cancer, and squamous cell carcinoma of the head and neck $(1,2)$. The activation of the EGFR pathway functions in the development and progression of cancer. Therefore, it is one of the targets of cancer chemotherapy using EGFR tyrosine kinase inhibitors (EGFR-TKIs), anti-EGFR antibodies, or immunotherapy against EGFR.

In NSCLC, activation mutations of the EGFR gene are detected in $\sim 15-20 \%$ of cases $(3,4)$. The majority of NSCLC harbors the wild-type EGFR gene, but it is primarily resistant to EGFR-TKIs $(5,6)$. Although previous studies, including ours, have identified potential chemosensitizers of EGFRTKIs in wild-type EGFR NSCLC, they have not reached clinical use (7-9). Thus, chemosensitizers to overcome the primary resistance to EGFR-TKIs in wild-type EGFR NSCLC are required. On the other hand, for patients with mutant EGFR NSCLC, first-generation EGFR-TKIs (gefitinib and erlotinib) are used as the first-line treatment. However, long-term treatment with EGFR-TKIs causes secondary resistance by several mechanisms, including the T790M resistance mutation, which is the most common mechanism of resistance, in approximately $50 \%$ of patients treated with first-generation EGFR-TKIs (10). Osimertinib, an oral, third-generation, irreversible EGFR-TKI, was developed to overcome resistance mediated by the T790M EGFR mutation $(11,12)$. In the phase III FLAURA trial, the efficacy and tolerability of osimertinib were found to be superior to those of standard EGFR-TKIs as first-line treatment for NSCLC, and osimertinib is currently recommended as first-line treatment (13). However, acquired resistance against osimertinib may develop and prevent an optimal outcome (14). Thus, chemosensitizers that overcome the acquired resistance to osimertinib in mutant EGFRNSCLC are required.

EGFR-TKIs are also used for patients with pancreatic cancer. In pancreatic cancer, EGFR is overexpressed, and 
therapy targeting EGFR has been reported as promising (15, 16). Indeed, in a phase III clinical trial, erlotinib combined with gemcitabine improved the clinical outcome compared with gemcitabine alone (17-19). However, the prognosis of pancreatic cancer is poor. Therefore, reagents that augment the effects of EGFR-TKIs in pancreatic cancer are needed. As osimertinib has a better toxicity profile than standard EGFR-TKIs in clinical studies $(12,13)$, osimertinib is a candidate EGFR-TKI for pancreatic cancer.

Brexpiprazole is a novel agent for depression and schizophrenia (20-22). Brexpiprazole was developed as a successor to aripiprazole, a dopamine-serotonin activity modulator with anti-cancer activity (23). Although the chemical and pharmacological properties of brexpiprazole are similar to those of aripiprazole, brexpiprazole has a better toxicity profile because of its lower intrinsic activity at D2 and D3 dopaminergic receptors $(21,24)$. We have recently revealed that, similar to aripiprazole, brexpiprazole has anticancer effects and acts as a chemosensitizer to 5-fluorouracil and gemcitabine in stem cells of NSCLC and pancreatic cancer (25). Moreover, we have previously reported that brexpiprazole chemosensitizes glioma stem cells, cancer stem cells of glioblastoma, to osimertinib by downregulating the expression of survivin, an anti-apoptotic protein (26). These results suggest that brexpiprazole acts as a chemosensitizer of osimertinib in other types of malignancies. However, it remains unclear whether the endogenous expression of survivin plays a major role in osimertinib resistance in NSCLC and pancreatic cancer, and whether brexpiprazole augments the effects of osimertinib through survivin suppression in these cancers. Thus, in this study, we explored the role of brexpiprazole as a chemosensitizer to osimertinib in wild-type EGFR NSCLC cells, osimertinib-resistant mutant EGFR NSCLC cells, and pancreatic cancer cells in vitro and in vivo, and examined the involvement of survivin in the osimertinib resistance mechanism.

\section{Materials and Methods}

Antibodies and reagents. Anti- $\beta$-actin (A1978) antibody was purchased from Sigma (St. Louis, MO, USA). Anti-survivin (\#2808) antibody was from Cell Signaling Technology, Inc. (Beverly, MA, USA). Osimertinib and YM155 were purchased from Chemscene LLC. (Monmouth Junction, NJ, USA) and dissolved in dimethyl sulfoxide (DMSO) to $10 \mathrm{mM}$ and $20 \mu \mathrm{M}$ stock solutions, respectively. Brexpiprazole was from Cayman Chemical Company (Ann Arbor, MI, USA) and was dissolved in DMSO to $10 \mathrm{mM}$ stock solution.

Cell culture and in vitro generation of an osimertinib-resistant cell line. Human non-small cell lung cancer (NSCLC) cell lines A549 and PC-9 were obtained from the Riken BioResource Center (Tsukuba, Japan). The human pancreatic cell line PANC-1 was from the Cell Resource Center for Biomedical Research, Institute of Development, Aging and Cancer, Tohoku University (Sendai, Japan).
These cell lines were cultured in DMEM/F12 medium supplemented with $10 \%$ fetal bovine serum, 100 units/ml of penicillin, and 100 $\mu \mathrm{g} / \mathrm{ml}$ of streptomycin as serum-cultured non-stem cancer cells. The establishment of cancer stem cells, A549 CSLC and PANC-1 CSLC cells, have been previously reported (27-30). The authenticity of A549 CSLC and PANC-1 CSLC cells was confirmed by genotyping of short tandem repeat (STR) loci (Bio-Synthesis, Inc., Lewisville, TX, USA) and comparing with the ATCC STR database for Human Cell Lines. These cancer stem cells were cultured, as previously described $(28,30,31)$, on collagen I-coated dishes (IWAKI, Tokyo, Japan) in stem cell culture medium [DMEM/F12 medium with 1\% B27 supplement (Thermo Fisher Scientific, Waltham, MA, USA), 20 ng/ml of EGF and FGF2 (Peprotech, Inc., Rocky Hill, NJ, USA), D(+)-glucose (final concentration, $26.2 \mathrm{mM}$ ), L-glutamine (final concentration, $4.5 \mathrm{mM}$ ), $100 \mathrm{units} / \mathrm{ml}$ of penicillin, and $100 \mu \mathrm{g} / \mathrm{ml}$ of streptomycin]. The stem cell culture medium was changed every 3 days, and EGF and FGF2 were supplemented in the medium every day. An osimertinib-resistant subline of PC-9 (PC-9-OR) was established by culturing in the presence of increasing concentrations of osimertinib (0.1-1.5 $\mu \mathrm{M})$ over a two-month period. PC-9-OR cells were maintained in the presence of $1.5 \mu \mathrm{M}$ osimertinib.

Cell viability assays. Viable and dead cells were identified by their ability and inability to exclude vital dyes, respectively $(23,30,32)$. In short, harvested cells were stained with $0.2 \%$ trypan blue as a vital dye, and the numbers of viable and dead cells were counted using a hemocytometer. The percent of dead cells (\%) was defined as $100 \times$ 'the number of dead cells'/('the number of viable cells' + 'the number of dead cells').

Immunoblot analysis. Cells or tumors were washed with PBS and lysed in RIPA buffer [10 mM Tris- $\mathrm{HCl}$ (pH 7.4), $0.1 \%$ SDS, $0.1 \%$ sodium deoxycholate, $1 \%$ NP-40, $150 \mathrm{mM} \mathrm{NaCl}, 1 \mathrm{mM}$ EDTA, $1.5 \mathrm{mM}$ $\mathrm{Na}_{3} \mathrm{VO}_{4}, 10 \mathrm{mM} \mathrm{NaF}, 10 \mathrm{mM}$ sodium pyrophosphate, $10 \mathrm{mM}$ sodium $\beta$-glycerophosphate, and $1 \%$ protease inhibitor cocktail set III (Sigma)]. After centrifugation for $10 \mathrm{~min}$ at $14,000 \times g$ at $4^{\circ} \mathrm{C}$, the supernatants were harvested as the cell lysates, and the protein concentration of cell lysates was measured using a BCA protein assay kit (Thermo Fisher Scientific). Cell lysates containing equal amounts of protein were separated by SDS-PAGE and transferred to polyvinylidene difluoride membranes. The membranes were probed with primary antibodies followed by an appropriate HRP-conjugated secondary antibody according to the manufacturer's instructions. The immunoreactive bands were visualized using Immobilon Western Chemiluminescent HRP Substrate (Merck Millipore, Darmstadt, Germany) and ChemiDoc Touch Imaging System (Bio-Rad, Hercules, CA, USA).

Gene silencing by siRNA. siRNAs against human survivin (BIRC5 \#2; HSS 179404, \#3; HSS 179405) and Medium GC Duplex \#2 of Stealth RNAi ${ }^{\mathrm{TM}}$ siRNA Negative Control Duplexes (non-targeting) were purchased from Thermo Fisher Scientific. Cells were transiently transfected with RNAs using Lipofectamine RNAiMAX ${ }^{\mathrm{TM}}$ (Thermo Fisher Scientific).

Mouse study. Mouse xenograft studies were carried out as previously described $(28,33)$. After anesthetization (intraperitoneal injection of medetomidine, midazolam, and butorphanol at $0.3 \mathrm{mg}$, $4 \mathrm{mg}$, and $5 \mathrm{mg}$ per $\mathrm{kg}$ of body weight, respectively), A549 cells $\left(1 \times 10^{6}\right)$ suspended in $200 \mu \mathrm{l}$ PBS were implanted subcutaneously in the flank region of 7-week-old male BALB/cAJcl-nu/nu mice 
(CLEA Japan, Inc., Tokyo, Japan). The tumor volume was assessed by measuring tumor diameters using calipers and calculated as the larger diameter $\times$ smaller diameter $\times$ height. For systemic administration of drugs, stock solutions of brexpiprazole $(4 \mathrm{mg} / \mathrm{ml})$ and osimertinib $(2 \mathrm{mg} / \mathrm{ml})$ were diluted in DMSO to prepare 100 $\mu l$ solutions for each injection, respectively. Brexpiprazole was administered by oral gavage to mice at $3 \mathrm{mg} / \mathrm{kg}$ twice a week and osimertinib was orally administered at $5 \mathrm{mg} / \mathrm{kg}$ five times a week. Drug treatment started 6 days after tumor implantation and confirmation of subcutaneous tumor formation, and tumor-bearing mice were randomized into four groups before the initiation of drug treatment. All animal experiment protocols were approved by the Animal Research Committee of Yamagata University.

Statistical analysis. The results are expressed as the means and standard deviation (SD). The differences were compared using the two-tailed $t$-test. $p$-Values $<0.05$ were considered significant and indicated with asterisks.

\section{Results}

Brexpiprazole sensitizes serum-cultured cancer cells and cancer stem cells of NSCLC and pancreatic cancer to osimertinib. First, the effects of co-treatment with brexpiprazole and osimertinib were examined. The representative NSCLC cell lines were: A549, which harbors wild-type EGFR, and PC-9-OR, which is a subline established by culturing PC-9 cells harboring a EGFR-TKIsensitive mutated EGFR gene with osimertinib (acquired resistance); the representative pancreatic cell line was PANC-1. Although the concentration of osimertinib used in the experiments $(2 \mu \mathrm{M})$ was sufficiently high to suppress the growth of osimertinib-sensitive PC-9 cells [data not shown and references $(34,35)]$, their growth was suppressed only mildly (Figure 1A), suggesting that these cells were resistant to osimertinib. Compared with osimertinib or brexpiprazole alone, co-treatment with osimertinib and brexpiprazole significantly reduced the cell number and increased cell death in these serum-cultured non-stem cancer cells (Figure 1A). Since we have previously reported that brexpiprazole sensitizes glioma stem cells to osimertinib (26), we examined whether brexpiprazole reduces osimertinib resistance in cancer stem cells of NSCLC and pancreatic cancer. Co-treatment with brexpiprazole and osimertinib significantly reduced the number of viable cells and increased death of cancer stem cells (Figure 2A).

Brexpiprazole reduces endogenous expression of survivin in NSCLC and pancreatic cancer cells, which is essential for their osimertinib resistance. Reduction of the expression of survivin, an anti-apoptotic protein, has been reported to sensitize cancer cells to EGFR-TKIs (36-39), and we have recently demonstrated that brexpiprazole reduces the expression of survivin in serum-cultured cancer cells, including A549 and PANC-1 cells, and cancer stem cells, including A549 CSLC and PANC-1 CSLC cells (25). Thus, we examined the expression of survivin in the serum-cultured cancer cells and cancer stem cells of NSCLC and pancreatic cancer that were treated with brexpiprazole at the concentration that induces sensitization. Brexpiprazole reduced the expression of survivin in these cells (Figure 1B and $2 \mathrm{~B})$.

To assess whether the expression of survivin plays a role in osimertinib resistance in these cells, we next examined whether YM155, a pharmacological inhibitor of survivin (40, 41), sensitizes these cells to osimertinib. After confirmation of the reduction of survivin expression by YM155 (Figure 3A), the osimertinib-resistant cell lines were co-treated with osimertinib and YM155. YM155 was found to sensitize these cell lines to osimertinib to a degree similar to that of brexpiprazole (Figure 3B). Moreover, to exclude the possibility of unintentional off-target effects of YM155, we investigated the effects of genetic downregulation of survivin by siRNA on the sensitivity to osimertinib in the resistant cell lines. After confirmation of the downregulating effects of two siRNAs (Figure 4A), the osimertinib-resistant cell lines were administered siRNAs against survivin and then treated with osimertinib. Suppression of survivin by siRNAs attenuated osimertinib resistance of osimertinib-resistant cell lines (Figure 4B). Together, these results demonstrate that the endogenous expression of survivin is an essential factor determining cellular resistance to osimertinib, and suggest that brexpiprazole sensitizes NSCLC and pancreatic cancer cells to osimertinib, at least in part, through the downregulation of survivin expression.

Brexpiprazole attenuates osimertinib-resistance in vivo. The above described results suggested that survivin inhibition effectively reverses the resistance to osimertinib in NSCLC and pancreatic cancer cell lines in vitro. In order to examine the therapeutic relevance of these in vitro findings in vivo, we evaluated the efficacy of co-treatment with osimertinib and brexpiprazole against the wild-type EGFR NSCLC cell line A549. After confirming the formation of tumors following implantation of A549 into nude mice, both osimertinib and brexpiprazole were repeatedly orally administered. As a result, tumor growth was significantly inhibited by the combination of osimertinib and brexpiprazole (Figure 5A). Although the mice that received osimertinib and brexpiprazole lost weight at the beginning of treatment, their body weight later recovered to a level similar to that of the other groups (Figure 5B). No adverse effects were observed. We also examined whether brexpiprazole reduces the expression of survivin in vivo, and found that its expression in the tumors was decreased (Figure 5C). 
A

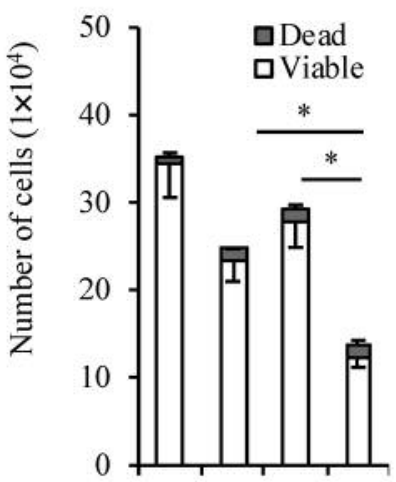

Osimertinib

Brexpiprazole
A549

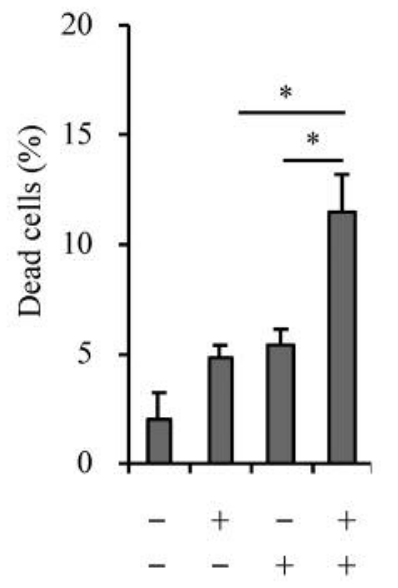

PC-9-OR

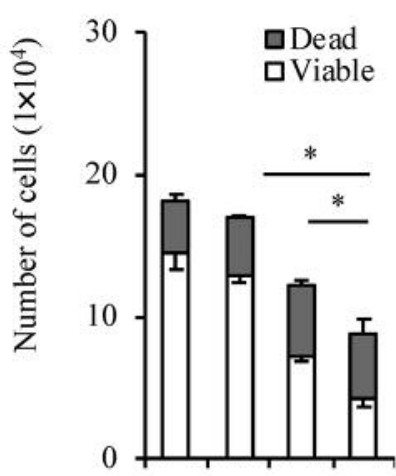

Osimertinib

Brexpiprazole $\quad-\quad++$

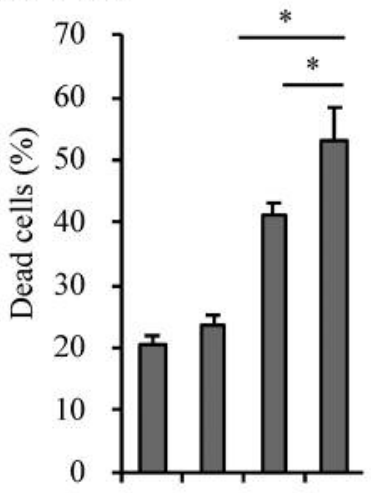

$-+-+$ $-\quad++$
B

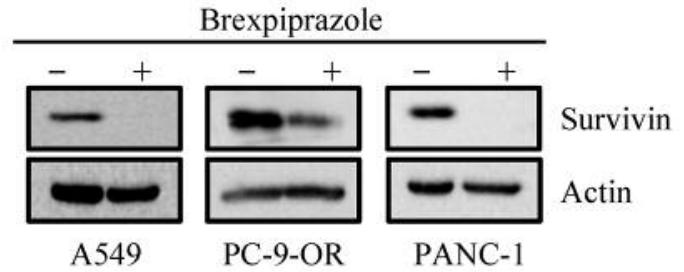

PANC-1

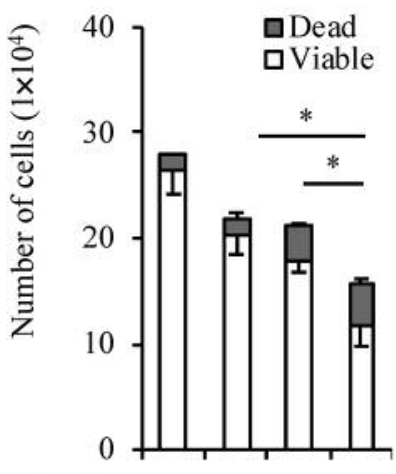

Osimertinib Brexpiprazole

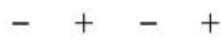

$-\quad++$

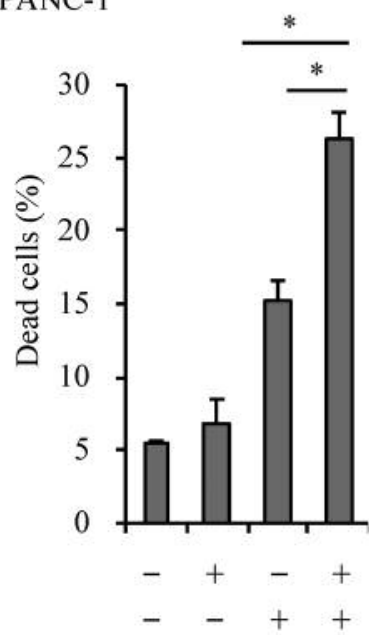

Figure 1. Brexpiprazole sensitizes serum-cultured cancer cells to osimertinib. Serum-cultured cancer cells were incubated with or without $2 \mu M$ osimertinib and with or without brexpiprazole for 3 days (brexpiprazole concentration was $2.5 \mu M$ for A549 and PANC-1, and $1.5 \mu M$ for PC-9-OR), and then subjected to cell viability assay using trypan blue (A). The initial number of A549 and PANC-1 cells was $5 \times 10^{4}$ and that of PC-9-OR cells was $1 \times 10^{5}$. The total number of cells (viable and dead) (left panels) and the percentage of dead cells (right panels) are shown. Values represent means $\pm S D$ from quadruplicate samples of a representative experiment repeated three times with similar results. $* p<0.05$. In the left panels, the number of viable cells was compared. Serum-cultured cancer cells were incubated with or without brexpiprazole (brexpiprazole concentration was $2.5 \mu \mathrm{M}$ for A549 and PANC-1, and 1.5 4 M for PC-9-OR) for 3 days, and then subjected to immunoblot analysis of survivin $(B)$. 


\section{Discussion}

As EGFR signaling is activated in several types of cancers, the effectiveness of therapies targeting EGFR has been clinically confirmed. However, their effectiveness is sometimes poor or limited because of primary or acquired resistance (42). Although several studies have been performed to find methods to overcome this resistance, such therapies have not reached clinical use. In this study, we found that brexpiprazole, a novel serotonin-dopamine activity modulator with an excellent safety profile, sensitized wild-type EGFR and osimertinib-resistant NSCLC and pancreatic cancer, which have intrinsic or acquired resistance, to osimertinib in vitro and in vivo. As brexpiprazole is currently clinically used for schizophrenia and depression with a known safety profile, our study suggests that it is a promising candidate chemosensitizer to osimertinib for EGFR-TKI-resistant cancers.

Several studies targeting EGFR-TKI resistance have been reported. For wild-type EGFR NSCLC, the therapeutic effects of erlotinib are increased by the inhibition of GLUT1 (8), restoration of the TUSC gene (43), inhibition of MER protooncogene protein tyrosine kinase (MERTK) (9), and pretreatment by cisplatin-based chemotherapy (44). However, these strategies have not been clinically applied. Regarding mutant EGFR NSCLC, osimertinib was originally developed to overcome the T790M mutation of EGFR that confers resistance to first- and second-generation EGFR-TKIs, but resistance to osimertinib is also acquired during treatment $(11,45)$. The mechanisms of the acquired resistance to osimertinib include loss of the T790M mutation, mutation of EGFR, such as C797S mutation, activation of bypassing pathways: HER2 amplification, MET amplification, PIK3CA activation mutation, up-regulation of AXL, and histological transition by small cell transformation or epithelial-mesenchymal transition (45-47). Although preclinical studies to overcome osimertinib resistance have been performed (47-50), a standard therapy for osimertinib-resistant mutant EGFR NSCLC has not been established $(14,46)$. For pancreatic cancer, preclinical and clinical studies to improve the effects of erlotinib have been carried out, but their results have not been applied for clinical use (51-54). Survivin, a member of the inhibitor of apoptosis protein family, mediates the resistance to EGFR-TKI in NSCLC, and its suppression indeed chemosensitizes NSCLC cells to erlotinib (36-39). However, it remains to be demonstrated whether inhibiting survivin expression is a viable approach to chemosensitize cancer cells to osimertinib. In this study, we confirmed that genetic and pharmacological inhibition of survivin expression sensitized NSCLC and pancreatic cancer cells, which have intrinsic or acquired osimertinib resistance, to osimertinib, and that brexpiprazole, which reduced survivin expression in these cells, effectively sensitized them to osimertinib. These results suggested that survivin is, at least in part, one of the major factors in osimertinib resistance, and that
A

A549 CSLC
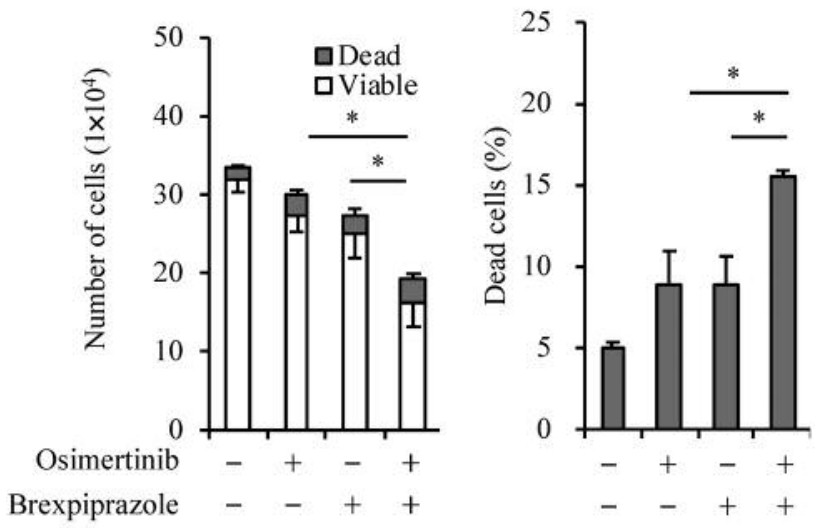

PANC-1 CSLC
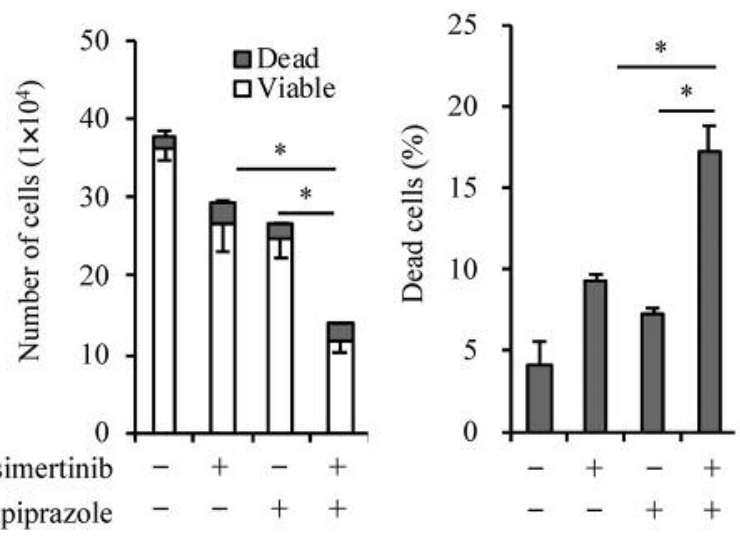

B

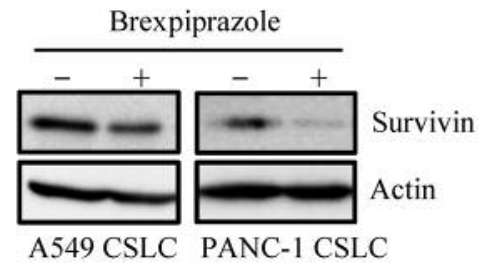

Figure 2. Brexpiprazole sensitizes cancer stem cells to osimertinib. Cancer stem cells were cultured with or without $2 \mu M$ osimertinib and with or without $2.5 \mu M$ brexpiprazole for 3 days, and then subjected to cell viability assay using trypan blue (A). The initial cell number was $1 \times 10^{5}$ cells for both A549 CSLC and PANC-1 CSLC. The total number of (viable and dead) (left panels) and the percentage of dead cells (right panels) are shown. Values represent means $\pm S D$ from quadruplicate samples of a representative experiment repeated three times with similar results. $* p<0.05$. In the left panels, the number of viable cells was compared. Cancer stem cells were cultured with or without $2.5 \mu \mathrm{M}$ brexpiprazole for 3 days, and then subjected to immunoblot analysis of survivin $(B)$.

its suppression prevents different resistant mechanisms in NSCLC and pancreatic cancer cells.

As survivin has been implicated in chemoresistance in cancer, it is regarded as a promising target for cancer therapy 
A

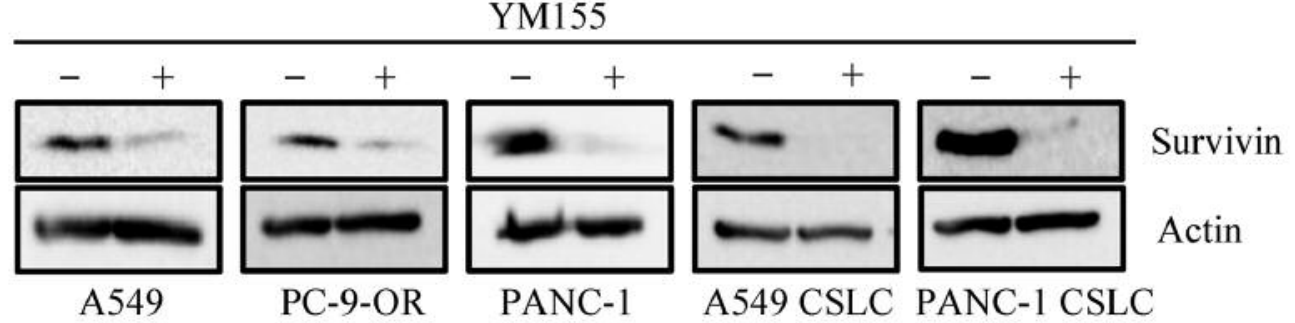

B
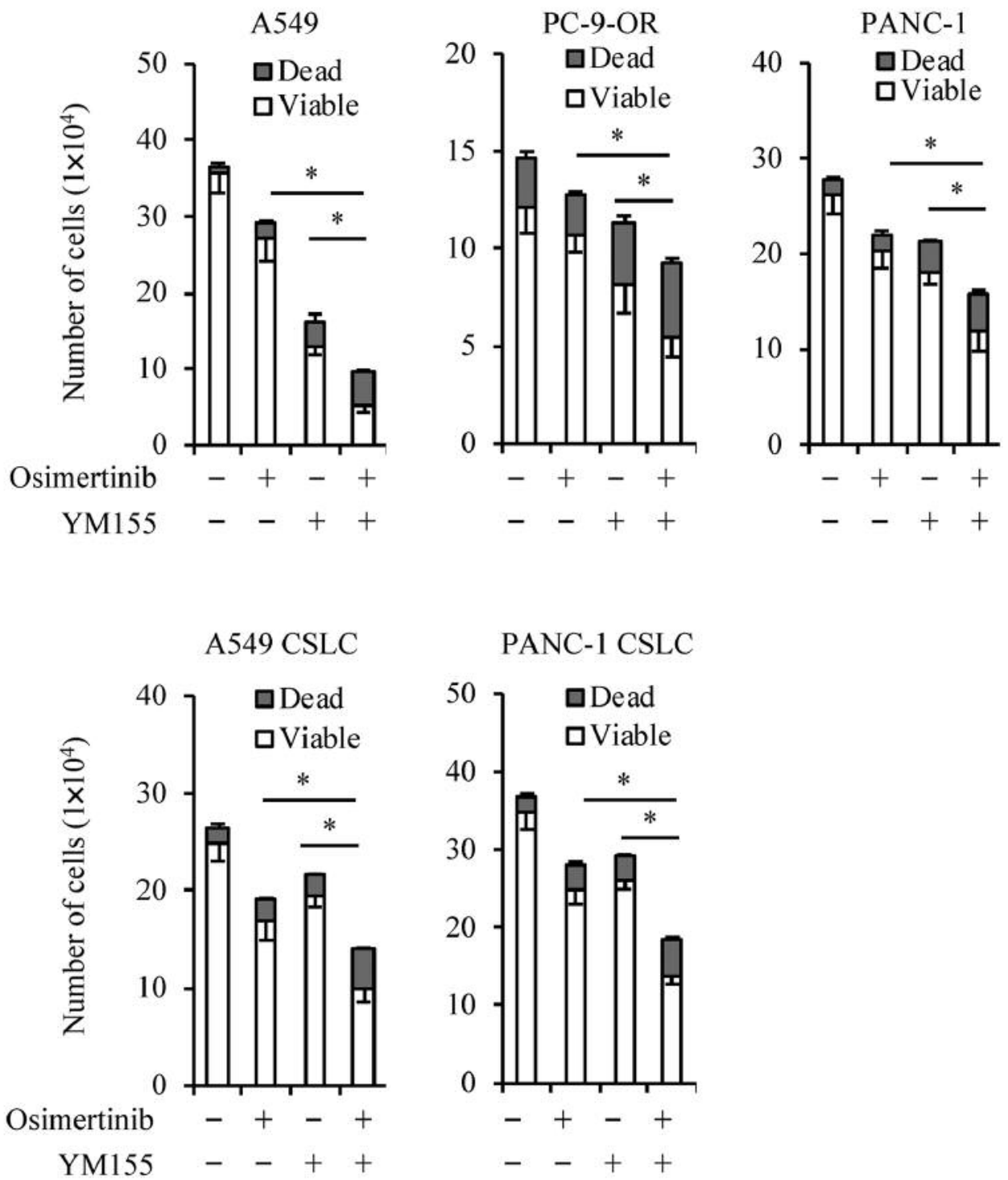

PANC-1 CSLC

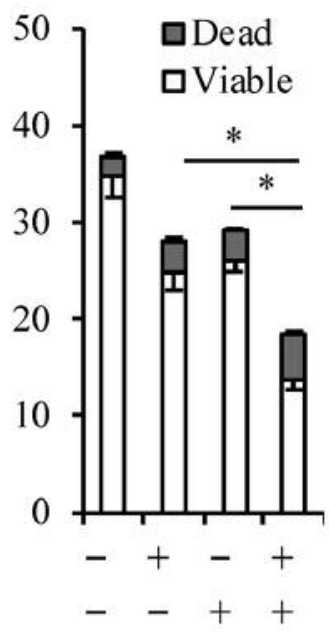

Figure 3. Pharmacological survivin inhibition by YM155 sensitizes osimertinib-resistant cells to osimertinib. The indicated serum-cultured cancer

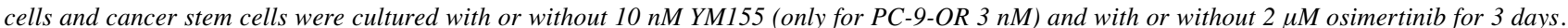
(A), extracts of cells treated with or without YM155 only were subjected to immunoblot analysis of survivin expression. (B) Cells were subjected to cell viability assay using trypan blue. The initial number of A549 and PANC-1 cells was $5 \times 10^{4}$ and that of PC-9-OR, A549 CSLC, and PANC-1 $C S L C$ cells was $1 \times 10^{5}$ cells. Values represent means $\pm S D$ from triplicate samples of a representative experiment repeated three times with similar results. *: $p<0.05$ (comparing viable cells). 


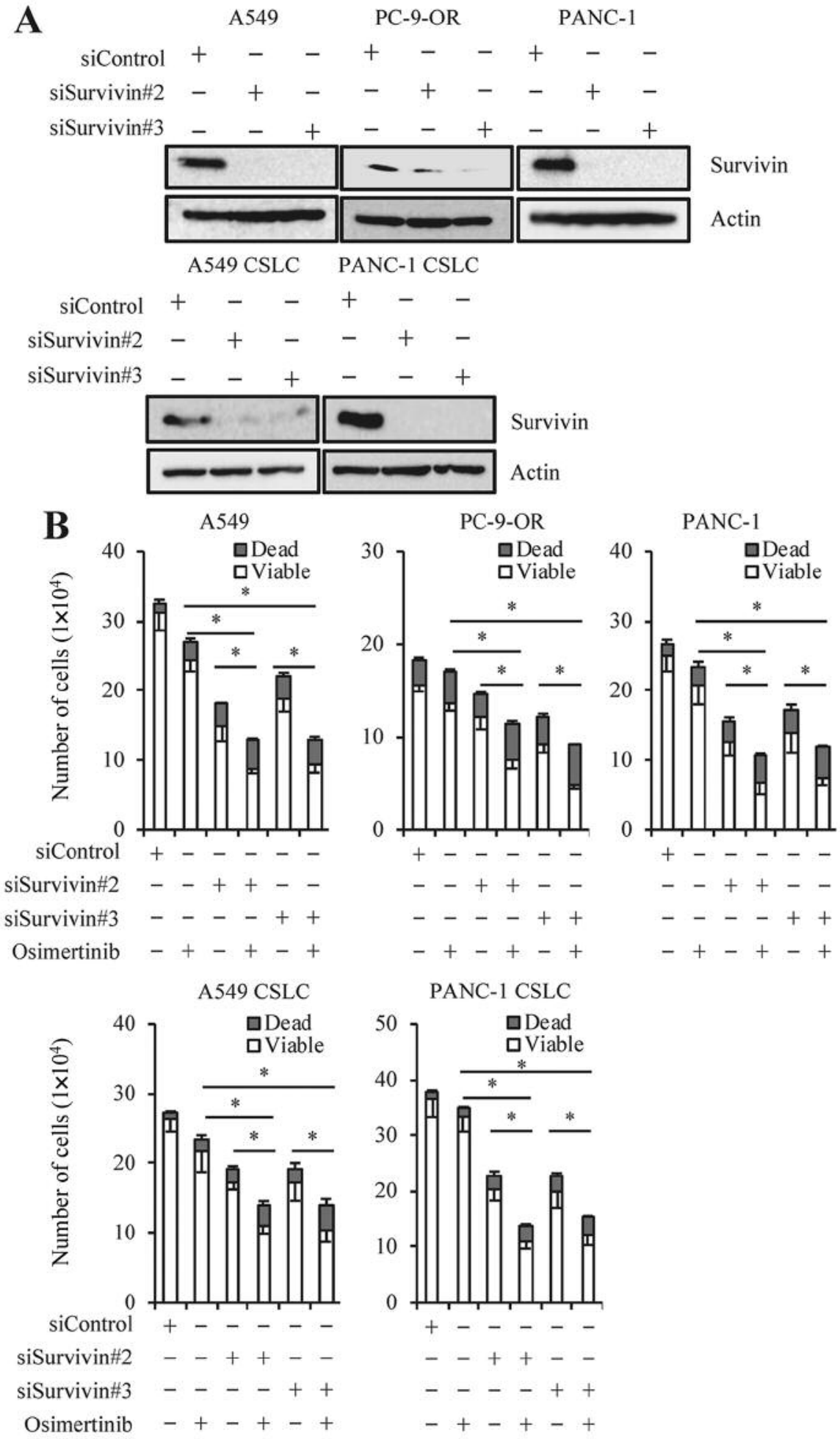

Figure 4. siRNA knockdown of survivin sensitizes osimertinib-resistant cancer cells to osimertinib. Non-targeting siRNA (siControl) or either of the siRNAs against survivin (siSurvivin\#2 or siSurvivin\#3) were introduced to the indicated serum-cultured cancer cells or cancer stem cells for 3 days. (A), cell extracts were subjected to immunoblot analysis of survivin expression. (B) Transfected cells were cultured with or without $2 \mu M$ osimertinib for 3 days, and were then subjected to cell viability assay using trypan blue. The initial number of A549 and PANC-1 cells was $5 \times 10^{4}$ and that of PC-9-OR, A549 CSLC, and PANC-1 CSLC cells was $1 \times 10^{5}$. Values represent means \pm SD from triplicate samples of a representative experiment repeated three times with similar results. ${ }^{*} p<0.05$ (comparing viable cells). 


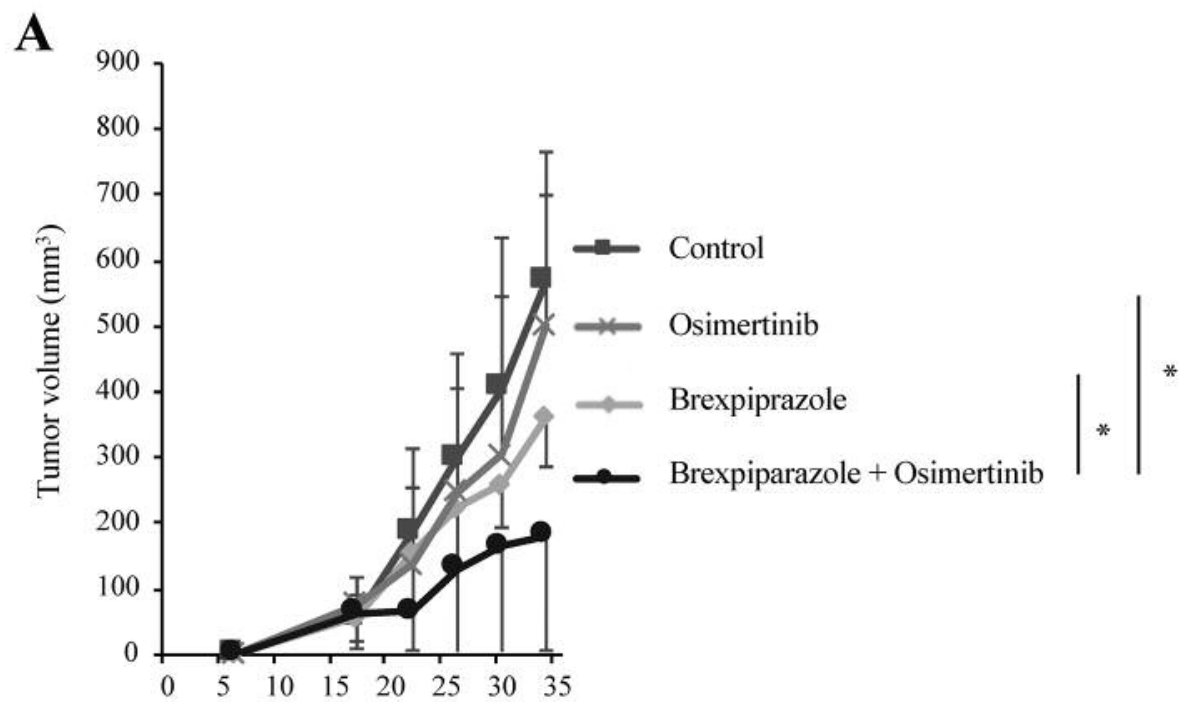

Days after implantation

C

Brexpiprazole

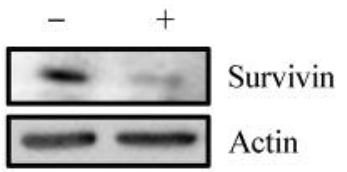

B

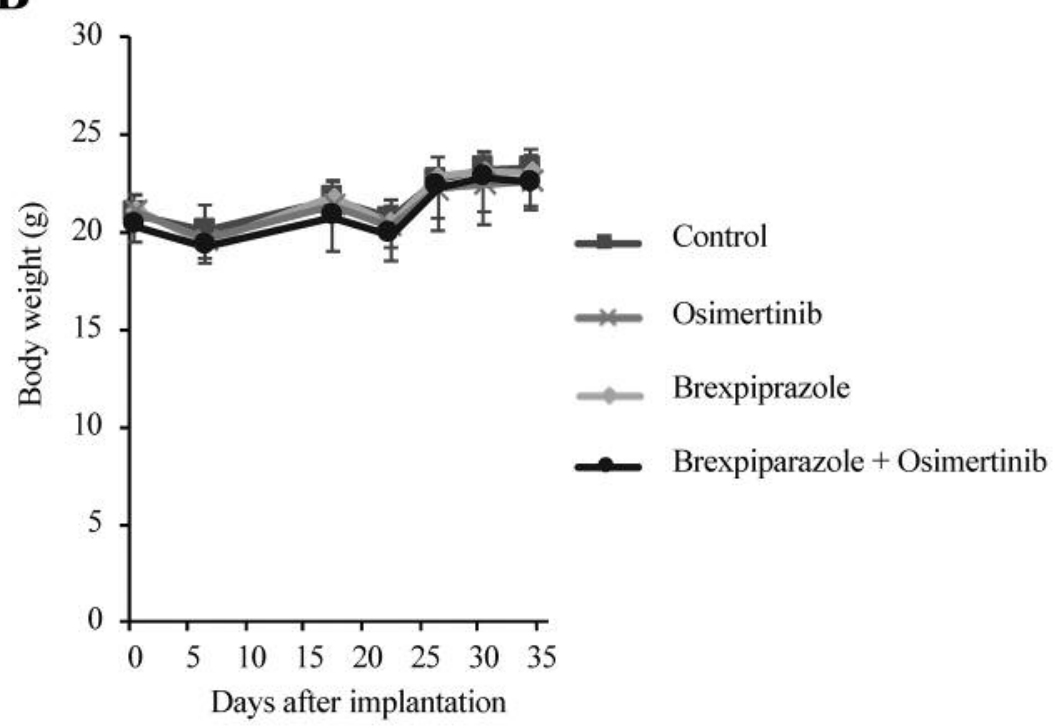

Figure 5. Dual administration of brexpiprazole and osimertinib reduces osimertinib-resistance in vivo. Wild-type EGFR NSCLC cells (A549, $1 \times 10^{6}$ cells) were subcutaneously implanted into the trunk of nude mice. After confirming tumor formation, the indicated drugs ( $3 \mathrm{mg} / \mathrm{kg}$ of brexpiprazole twice a week, $5 \mathrm{mg} / \mathrm{kg}$ of osimertinib 5 times a week, or both) were orally administered. (A), the tumor volume of each group is shown ( $n=8$, each group).(B). The body weight of the mice is presented. $(C)$. The tumor tissues excised from the control and brexpiprazole-treated mice were subjected to immunoblot analysis of survivin. ${ }^{*} p<0.05$, comparison at the end of the study.

(55). Survivin is targeted by several strategies such as small molecule inhibitors, transcriptional suppression by antisense oligonucleotide, or RNA interference (56). Although clinical trials targeting survivin have been performed, the efficacy of these therapies has not been confirmed or is only limited (57). YM155, a small molecule that pharmacologically inhibits survivin, exhibits a favorable safety tolerability profile (58).
However, clinical trials using YM155 are insufficient and there are many unknown factors (59-61). LY2181308, a survivin antisense oligonucleotide, has exhibited a favorable toxicity profile in a phase I clinical trial (62). However, its efficacy was not confirmed in a randomized phase II clinical trial for castration-resistant prostate cancer (63). From the perspective of drug repurposing, we have previously 
demonstrated that clinically used antipsychotics, olanzapine and aripiprazole, reduce survivin expression $(23,32)$, but olanzapine may cause deep sedation (64) and aripiprazole causes akathisia $(20,21)$. Moreover, cancer patients are frail and sensitive to medications due to insufficient kidney and liver functions. Brexpiprazole is better than aripiprazole because it has fewer side effects such as akathisia and extrapyramidal symptoms $(21,24)$. Brexpiprazole is used as an antipsychotic and antidepressant $(65,66)$, and thus may be effective from the standpoint of psycho-oncology. Additionally, it is widely used worldwide and has been approved by the Food and Drug Administration. Therefore, it can be promptly adapted to clinical settings.

In this study, we showed that the endogenous expression of survivin is a major factor in osimertinib resistance in wild-type and mutant EGFR NSCLC, and pancreatic cancer, and that brexpiprazole chemosensitizes these cancer cells to osimertinib, most likely through suppression of survivin expression. In conclusion, brexpiprazole is a promising drug in combination with osimertinib to treat NSCLC or pancreatic cancer.

\section{Conflicts of Interest}

The Authors declare no conflicts of interest regarding this study.

\section{Authors' Contributions}

T.S., S. Suzuki, C.K., M.O., and M.Y. designed the research. T.S., S. Suzuki, and S. Seino performed the experiments. T.S., S. Suzuki, M.O., and M.Y. wrote the original paper, and T.S., S. Suzuki, K.T., S. Shizuka, T.Y. C.K., M.O., and M.Y. reviewed and edited paper. All Authors discussed the results and contributed to the final manuscript.

\section{Acknowledgements}

This study was supported by Grants-in-Aid for Scientific Research, for Challenging Exploratory Research, and for Young Scientists from the Ministry of Education, Culture, Sports, Science and Technology of Japan.

\section{References}

1 Yarden Y and Pines G: The ERBB network: at last, cancer therapy meets systems biology. Nat Rev Cancer 12(8): 553-563, 2012. PMID: 22785351. DOI: $10.1038 / \mathrm{nrc} 3309$

2 Sigismund S, Avanzato D and Lanzetti L: Emerging functions of the EGFR in cancer. Mol Oncol 12(1): 3-20, 2018. PMID: 29124875. DOI: $10.1002 / 1878-0261.12155$

3 Yun CH, Boggon TJ, Li Y, Woo MS, Greulich H, Meyerson M and Eck MJ: Structures of lung cancer-derived EGFR mutants and inhibitor complexes: mechanism of activation and insights into differential inhibitor sensitivity. Cancer Cell 11(3): 217-227, 2007. PMID: 17349580. DOI: 10.1016/j.ccr.2006.12.017

4 Cancer Genome Atlas Research N: Comprehensive molecular profiling of lung adenocarcinoma. Nature 511(7511): 543-550, 2014. PMID: 25079552. DOI: 10.1038/nature13385
5 Paez JG, Janne PA, Lee JC, Tracy S, Greulich H, Gabriel S, Herman P, Kaye FJ, Lindeman N, Boggon TJ, Naoki K, Sasaki H, Fujii Y, Eck MJ, Sellers WR, Johnson BE and Meyerson M: EGFR mutations in lung cancer: correlation with clinical response to gefitinib therapy. Science 304(5676): 1497-1500, 2004. PMID: 15118125 . DOI: $10.1126 /$ science. 1099314

6 Zhu CQ, da Cunha Santos G, Ding K, Sakurada A, Cutz JC, Liu N, Zhang T, Marrano P, Whitehead M, Squire JA, Kamel-Reid S, Seymour L, Shepherd FA, Tsao MS and National Cancer Institute of Canada Clinical Trials Group Study BR: Role of KRAS and EGFR as biomarkers of response to erlotinib in National Cancer Institute of Canada Clinical Trials Group Study BR.21. J Clin Oncol 26(26): 4268-4275, 2008. PMID: 18626007. DOI: 10.1200/JCO.2007.14.8924

7 Li YL, Hu X, Li QY, Wang F, Zhang B, Ding K, Tan BQ, Lin NM and Zhang C: Shikonin sensitizes wildtype EGFR NSCLC cells to erlotinib and gefitinib therapy. Mol Med Rep 18(4): 38823890, 2018. PMID: 30106133. DOI: 10.3892/mmr. 2018.9347

8 Suzuki S, Okada M, Takeda H, Kuramoto K, Sanomachi T, Togashi K, Seino S, Yamamoto M, Yoshioka T and Kitanaka C: Involvement of GLUT1-mediated glucose transport and metabolism in gefitinib resistance of non-small-cell lung cancer cells. Oncotarget 9(66): 32667-32679, 2018. PMID: 30220973. DOI: $10.18632 /$ oncotarget.25994

9 Yan D, Parker RE, Wang X, Frye SV, Earp HS, 3rd, DeRyckere D and Graham DK: MERTK promotes resistance to irreversible EGFR tyrosine kinase inhibitors in non-small cell lung cancers expressing wild-type EGFR family members. Clin Cancer Res 24(24): 6523-6535, 2018. PMID: 30194074. DOI: 10.1158/ 1078-0432.CCR-18-0040

10 Kobayashi S, Boggon TJ, Dayaram T, Janne PA, Kocher O, Meyerson M, Johnson BE, Eck MJ, Tenen DG and Halmos B: EGFR mutation and resistance of non-small-cell lung cancer to gefitinib. N Engl J Med 352(8): 786-792, 2005. PMID: 1572 8811. DOI: $10.1056 /$ NEJMoa044238

11 Janne PA, Yang JC, Kim DW, Planchard D, Ohe Y, Ramalingam SS, Ahn MJ, Kim SW, Su WC, Horn L, Haggstrom D, Felip E, Kim JH, Frewer P, Cantarini M, Brown KH, Dickinson PA, Ghiorghiu S and Ranson M: AZD9291 in EGFR inhibitor-resistant non-small-cell lung cancer. N Engl J Med 372(18): 1689-1699, 2015. PMID: 25923549. DOI: 10.1056/NEJMo a1411817

12 Mok TS, Wu YL, Ahn MJ, Garassino MC, Kim HR, Ramalingam SS, Shepherd FA, He Y, Akamatsu H, Theelen WS, Lee CK, Sebastian M, Templeton A, Mann H, Marotti M, Ghiorghiu S, Papadimitrakopoulou VA and Investigators A: Osimertinib or platinum-pemetrexed in EGFR T790M-positive lung cancer. N Engl J Med 376(7): 629-640, 2017. PMID: 27959700. DOI: 10.1056/NEJMoa1612674

13 Soria JC, Ohe Y, Vansteenkiste J, Reungwetwattana T, Chewaskulyong B, Lee KH, Dechaphunkul A, Imamura F, Nogami N, Kurata T, Okamoto I, Zhou C, Cho BC, Cheng Y, Cho EK, Voon PJ, Planchard D, Su WC, Gray JE, Lee SM, Hodge R, Marotti M, Rukazenkov Y, Ramalingam SS and Investigators $\mathrm{F}$ : Osimertinib in untreated EGFR-mutated advanced non-small-cell lung cancer. N Engl J Med 378(2): 113125, 2018. PMID: 29151359. DOI: 10.1056/NEJMoa 1713137

14 Murtuza A, Bulbul A, Shen JP, Keshavarzian P, Woodward BD, Lopez-Diaz FJ, Lippman SM and Husain H: Novel thirdgeneration EGFR tyrosine kinase inhibitors and strategies to overcome therapeutic resistance in lung cancer. Cancer Res 
79(4): 689-698, 2019. PMID: 30718357. DOI: 10.1158/0008 5472.CAN-18-1281

15 Ueda S, Ogata S, Tsuda H, Kawarabayashi N, Kimura M, Sugiura Y, Tamai S, Matsubara O, Hatsuse K and Mochizuki H: The correlation between cytoplasmic overexpression of epidermal growth factor receptor and tumor aggressiveness: poor prognosis in patients with pancreatic ductal adenocarcinoma. Pancreas 29(1): e1-8, 2004. PMID: 15211117.

16 Lee J, Jang KT, Ki CS, Lim T, Park YS, Lim HY, Choi DW, Kang WK, Park K and Park JO: Impact of epidermal growth factor receptor (EGFR) kinase mutations, EGFR gene amplifications, and KRAS mutations on survival of pancreatic adenocarcinoma. Cancer 109(8): 1561-1569, 2007. PMID: 17354229. DOI: $10.1002 / \mathrm{cncr} .22559$

17 Moore MJ, Goldstein D, Hamm J, Figer A, Hecht JR, Gallinger S, Au HJ, Murawa P, Walde D, Wolff RA, Campos D, Lim R, Ding K, Clark G, Voskoglou-Nomikos T, Ptasynski M and Parulekar W: Erlotinib plus gemcitabine compared with gemcitabine alone in patients with advanced pancreatic cancer: a phase III trial of the National Cancer Institute of Canada Clinical Trials Group. J Clin Oncol 25(15): 1960-1966, 2007. PMID: 17452677. DOI: 10.1200/jco.2006.07.9525

18 Okusaka T, Furuse J, Funakoshi A, Ioka T, Yamao K, Ohkawa S, Boku N, Komatsu Y, Nakamori S, Iguchi H, Ito T, Nakagawa $\mathrm{K}$ and Nakachi K: Phase II study of erlotinib plus gemcitabine in Japanese patients with unresectable pancreatic cancer. Cancer Sci 102(2): 425-431, 2011. PMID: 21175992. DOI: 10.1111/ j.1349-7006.2010.01810.x

19 Yang ZY, Yuan JQ, Di MY, Zheng DY, Chen JZ, Ding H, Wu $\mathrm{XY}$, Huang YF, Mao C and Tang JL: Gemcitabine plus erlotinib for advanced pancreatic cancer: a systematic review with metaanalysis. PLoS One 8(3): e57528, 2013. PMID: 23472089. DOI: 10.1371/journal.pone.0057528

20 Aladeen T, Westphal E, Lee Y, Rong C, Rainka M, Capote H and McIntyre RS: The use of brexpiprazole amongst individuals with insufficient outcomes with aripiprazole or bupropion: A case series. Perspect Psychiatr Care 54(4): 507-513, 2018. PMID: 29427512. DOI: $10.1111 / \mathrm{ppc} .12258$

21 Frankel JS and Schwartz TL: Brexpiprazole and cariprazine: distinguishing two new atypical antipsychotics from the original dopamine stabilizer aripiprazole. Ther Adv Psychopharmacol 7(1): 29-41, 2017. PMID: 28101322. DOI: 10.1177/20451 25316672136

22 Correll CU, Skuban A, Ouyang J, Hobart M, Pfister S, McQuade RD, Nyilas M, Carson WH, Sanchez R and Eriksson H: Efficacy and safety of brexpiprazole for the treatment of acute schizophrenia: a 6-week randomized, double-blind, placebocontrolled trial. Am J Psychiatry 172(9): 870-880, 2015. PMID: 25882325. DOI: 10.1176/appi.ajp.2015.14101275

23 Suzuki S, Okada M, Kuramoto K, Takeda H, Sakaki H, Watarai $\mathrm{H}$, Sanomachi $\mathrm{T}$, Seino S, Yoshioka $\mathrm{T}$ and Kitanaka $\mathrm{C}$ : Aripiprazole, an antipsychotic and partial dopamine agonist, inhibits cancer stem cells and reverses chemoresistance. Anticancer Res 36(10): 5153-5161, 2016. PMID: 27798875. DOI: 10.21873 /anticanres.11085

24 Citrome L, Ota A, Nagamizu K, Perry P, Weiller E and Baker RA: The effect of brexpiprazole (OPC-34712) and aripiprazole in adult patients with acute schizophrenia: results from a randomized, exploratory study. Int Clin Psychopharmacol 31(4): 192-201, 2016. PMID: 26963842. DOI: 10.1097/YIC.0000000 000000123
25 Suzuki S, Yamamoto M, Togashi K, Sanomachi T, Sugai A, Seino S, Yoshioka T, Kitanaka C and Okada M: In vitro and in vivo anti-tumor effects of brexpiprazole, a newly-developed serotonin-dopamine activity modulator with an improved safety profile. Oncotarget 10(37): 3547-3558, 2019. PMID: 31191825. DOI: $10.18632 /$ oncotarget.26949

26 Suzuki S, Yamamoto M, Sanomachi T, Togashi K, Sugai A, Seino S, Yoshioka T, Kitanaka C and Okada M: Brexpiprazole, a serotonin-dopamine activity modulator, can sensitize glioma stem cells to osimertinib, a third-generation EGFR-TKI, via survivin reduction. Cancers (Basel) 11(7), 2019. PMID: 31284441. DOI: $10.3390 /$ cancers 11070947

27 Gaviraghi M, Tunici P, Valensin S, Rossi M, Giordano C, Magnoni L, Dandrea M, Montagna L, Ritelli R, Scarpa A and Bakker A: Pancreatic cancer spheres are more than just aggregates of stem marker-positive cells. Biosci Rep 31(1): 4555, 2011. PMID: 20426768. DOI: 10.1042/BSR20100018

28 Okada M, Shibuya K, Sato A, Seino S, Suzuki S, Seino M and Kitanaka C: Targeting the K-Ras--JNK axis eliminates cancer stem-like cells and prevents pancreatic tumor formation. Oncotarget 5(13): 5100-5112, 2014. PMID: 24947996. DOI: 10.18632/oncotarget.2087

29 Okada M, Shibuya K, Sato A, Seino S, Watanabe E, Suzuki S, Seino $M$ and Kitanaka C: Specific role of JNK in the maintenance of the tumor-initiating capacity of A549 human non-small cell lung cancer cells. Oncol Rep 30(4): 1957-1964, 2013. PMID: 23912840. DOI: 10.3892/or.2013.2655

30 Suzuki S, Okada M, Shibuya K, Seino M, Sato A, Takeda H, Seino S, Yoshioka T and Kitanaka C: JNK suppression of chemotherapeutic agents-induced ROS confers chemoresistance on pancreatic cancer stem cells. Oncotarget 6(1): 458-470, 2015. PMID: 25473894. DOI: 10.18632/oncotarget.2693

31 Okada M, Kuramoto K, Takeda H, Watarai H, Sakaki H, Seino S, Seino M, Suzuki S and Kitanaka C: The novel JNK inhibitor AS602801 inhibits cancer stem cells in vitro and in vivo. Oncotarget 7(19): 27021-27032, 2016. PMID: 27027242. DOI: 10.18632 /oncotarget.8395

32 Sanomachi T, Suzuki S, Kuramoto K, Takeda H, Sakaki H, Togashi K, Seino S, Yoshioka T, Okada M and Kitanaka C: Olanzapine, an atypical antipsychotic, inhibits survivin expression and sensitizes cancer cells to chemotherapeutic agents. Anticancer Res 37(11): 6177-6188, 2017. PMID: 29061799. DOI: 10.21873 /anticanres.12067

33 Shibuya K, Okada M, Suzuki S, Seino M, Seino S, Takeda H and Kitanaka C: Targeting the facilitative glucose transporter GLUT1 inhibits the self-renewal and tumor-initiating capacity of cancer stem cells. Oncotarget 6(2): 651-661, 2015. PMID: 25528771. DOI: 10.18632/oncotarget.2892

34 Nukaga S, Yasuda H, Tsuchihara K, Hamamoto J, Masuzawa K, Kawada I, Naoki K, Matsumoto S, Mimaki S, Ikemura S, Goto $\mathrm{K}$, Betsuyaku T and Soejima K: Amplification of EGFR wildtype alleles in non-small cell lung cancer cells confers acquired resistance to mutation-selective EGFR tyrosine kinase inhibitors. Cancer Res 77(8): 2078-2089, 2017. PMID: 28202511. DOI: 10.1158/0008-5472.CAN-16-2359

35 Hirano T, Yasuda H, Tani T, Hamamoto J, Oashi A, Ishioka K, Arai D, Nukaga S, Miyawaki M, Kawada I, Naoki K, Costa DB, Kobayashi SS, Betsuyaku T and Soejima K: In vitro modeling to determine mutation specificity of EGFR tyrosine kinase inhibitors against clinically relevant EGFR mutants in non- 
small-cell lung cancer. Oncotarget 6(36): 38789-38803, 2015 PMID: 26515464. DOI: 10.18632/oncotarget.5887

36 Okamoto K, Okamoto I, Hatashita E, Kuwata K, Yamaguchi H, Kita A, Yamanaka K, Ono M and Nakagawa K: Overcoming erlotinib resistance in EGFR mutation-positive non-small cell lung cancer cells by targeting survivin. Mol Cancer Ther 11(1): 204-213, 2012. PMID: 22075159. DOI: 10.1158/1535-7163.mct11-0638

37 Morgillo F, Woo JK, Kim ES, Hong WK and Lee HY: Heterodimerization of insulin-like growth factor receptor/epidermal growth factor receptor and induction of survivin expression counteract the antitumor action of erlotinib. Cancer Res 66(20): 10100-10111, 2006. PMID: 17047074. DOI: 10.1158/00085472.can-06-1684

38 Okamoto K, Okamoto I, Okamoto W, Tanaka K, Takezawa K, Kuwata K, Yamaguchi H, Nishio K and Nakagawa K: Role of survivin in EGFR inhibitor-induced apoptosis in non-small cell lung cancers positive for EGFR mutations. Cancer Res 70(24): 10402-10410, 2010. PMID: 21159653. DOI: 10.1158/00085472.CAN-10-2438

39 Dai CH, Shu Y, Chen P, Wu JN, Zhu LH, Yuan RX, Long WG, Zhu YM and Li J: YM155 sensitizes non-small cell lung cancer cells to EGFR-tyrosine kinase inhibitors through the mechanism of autophagy induction. Biochim Biophys Acta Mol Basis Dis 1864(12): 3786-3798, 2018. PMID: 30315932. DOI: 10.1016/ j.bbadis.2018.10.015

40 Nakahara T, Kita A, Yamanaka K, Mori M, Amino N, Takeuchi M, Tominaga F, Hatakeyama S, Kinoyama I, Matsuhisa A, Kudoh M and Sasamata M: YM155, a novel small-molecule survivin suppressant, induces regression of established human hormone-refractory prostate tumor xenografts. Cancer Res 67(17): 8014-8021, 2007. PMID: 17804712. DOI: 10.1158/ 0008-5472.CAN-07-1343

41 Ryan BM, O'Donovan N and Duffy MJ: Survivin: a new target for anti-cancer therapy. Cancer Treat Rev 35(7): 553-562, 2009. PMID: 19559538. DOI: 10.1016/j.ctrv.2009.05.003

42 Yamaoka T, Ohba $\mathrm{M}$ and Ohmori T: Molecular-targeted therapies for epidermal growth factor receptor and its resistance mechanisms. Int J Mol Sci 18(11), 2017. PMID: 29140271. DOI: 10.3390/ijms 18112420

43 Dai B, Yan S, Lara-Guerra H, Kawashima H, Sakai R, Jayachandran G, Majidi M, Mehran R, Wang J, Bekele BN, Baladandayuthapani V, Yoo SY, Wang Y, Ying J, Meng F, Ji L and Roth JA: Exogenous restoration of TUSC2 expression induces responsiveness to erlotinib in wildtype epidermal growth factor receptor (EGFR) lung cancer cells through context specific pathways resulting in enhanced therapeutic efficacy. PLoS One 10(6): e0123967, 2015. PMID: 26053020. DOI: 10.1371/journal.pone.0123967

44 Raimbourg J, Joalland MP, Cabart M, de Plater L, Bouquet F, Savina A, Decaudin D, Bennouna J, Vallette FM and Lalier L: Sensitization of EGFR wild-type non-small cell lung cancer cells to egfr-tyrosine kinase inhibitor erlotinib. Mol Cancer Ther 16(8): 1634-1644, 2017. PMID: 28522592. DOI: 10.1158/15357163.MCT-17-0075

45 Minari R, Bordi $\mathrm{P}$ and Tiseo M: Third-generation epidermal growth factor receptor-tyrosine kinase inhibitors in T790Mpositive non-small cell lung cancer: review on emerged mechanisms of resistance. Transl Lung Cancer Res 5(6): 695708, 2016. PMID: 28149764. DOI: 10.21037/tlcr.2016.12.02
46 Tang ZH and Lu JJ: Osimertinib resistance in non-small cell lung cancer: Mechanisms and therapeutic strategies. Cancer Lett 420: 242-246, 2018. PMID: 29425688. DOI: 10.1016/j.canlet. 2018.02.004

47 Le X, Puri S, Negrao MV, Nilsson MB, Robichaux J, Boyle T, Hicks JK, Lovinger KL, Roarty E, Rinsurongkawong W, Tang M, Sun H, Elamin Y, Lacerda LC, Lewis J, Roth JA, Swisher SG, Lee JJ, William WN Jr., Glisson BS, Zhang J, Papadimitrakopoulou VA, Gray JE and Heymach JV: Landscape of EGFR-dependent and -independent resistance mechanisms to osimertinib and continuation therapy beyond progression in EGFR-mutant NSCLC. Clin Cancer Res 24(24): 6195-6203, 2018. PMID: 30228210. DOI: 10.1158/10780432.CCR-18-1542

48 Taniguchi H, Yamada T, Wang R, Tanimura K, Adachi Y, Nishiyama A, Tanimoto A, Takeuchi S, Araujo LH, Boroni M, Yoshimura A, Shiotsu S, Matsumoto I, Watanabe S, Kikuchi T, Miura S, Tanaka H, Kitazaki T, Yamaguchi H, Mukae H, Uchino J, Uehara H, Takayama K and Yano S: AXL confers intrinsic resistance to osimertinib and advances the emergence of tolerant cells. Nat Commun 10(1): 259, 2019. PMID: 30651547. DOI: 10.1038/s41467-018-08074-0

49 Namba K, Shien K, Takahashi Y, Torigoe H, Sato H, Yoshioka T, Takeda T, Kurihara E, Ogoshi Y, Yamamoto H, Soh J, Tomida $\mathrm{S}$ and Toyooka S: Activation of AXL as a preclinical acquired resistance mechanism against osimertinib treatment in EGFRmutant non-small cell lung cancer cells. Mol Cancer Res 17(2): 499-507, 2019. PMID: 30463991. DOI: 10.1158/15417786.MCR-18-0628

50 Romaniello D, Mazzeo L, Mancini M, Marrocco I, Noronha A, Kreitman M, Srivastava S, Ghosh S, Lindzen M, Salame TM, Onn A, Bar J and Yarden Y: A Combination of approved antibodies overcomes resistance of lung cancer to osimertinib by blocking bypass pathways. Clin Cancer Res 24(22): 5610-5621, 2018. PMID: 29967248. DOI: 10.1158/1078-0432.CCR-18-0450

51 Zheng H, Yang L, Kang Y, Chen M, Lin S, Xiang Y, Li C, Dai $X$, Huang $X$, Liang $G$ and Zhao C: Alantolactone sensitizes human pancreatic cancer cells to EGFR inhibitors through the inhibition of STAT3 signaling. Mol Carcinog 58(4): 565-576, 2019. PMID: 30520143. DOI: 10.1002/mc.22951

$52 \mathrm{Du}$ J, He Y, Wu W, Li P, Chen Y, Hu Z and Han Y: Targeting EphA2 with miR-124 mediates Erlotinib resistance in K-RAS mutated pancreatic cancer. J Pharm Pharmacol 71(2): 196-205, 2019. PMID: 30604411. DOI: 10.1111/jphp.12941

53 Halfdanarson TR, Foster NR, Kim GP, Meyers JP, Smyrk TC, McCullough AE, Ames MM, Jaffe JP and Alberts SR: A phase II randomized trial of panitumumab, erlotinib, and gemcitabine versus erlotinib and gemcitabine in patients with untreated, metastatic pancreatic adenocarcinoma: North Central Cancer Treatment Group Trial N064B (Alliance). Oncologist, 2019. PMID: 30679315. DOI: 10.1634/theoncologist.2018-0878

54 Veschi S, De Lellis L, Florio R, Lanuti P, Massucci A, Tinari N, De Tursi M, di Sebastiano P, Marchisio M, Natoli C and Cama A: Effects of repurposed drug candidates nitroxoline and nelfinavir as single agents or in combination with erlotinib in pancreatic cancer cells. J Exp Clin Cancer Res 37(1): 236, 2018. PMID: 30241558. DOI: 10.1186/s13046-018-0904-2

55 Mobahat M, Narendran A and Riabowol K: Survivin as a preferential target for cancer therapy. Int J Mol Sci 15(2): 24942516, 2014. PMID: 24531137. DOI: 10.3390/ijms15022494 
56 Soleimanpour E and Babaei E: Survivin as a potential target for cancer therapy. Asian Pac J Cancer Prev 16(15): 6187-6191, 2015. PMID: 26434815. DOI: 10.7314/apjcp.2015.16.15.6187

57 Wang S, Xu Y, Chan HF, Kim HW, Wang Y, Leong KW and Chen M: Nanoparticle-mediated inhibition of survivin to overcome drug resistance in cancer therapy. J Control Release 240: 454-464, 2016. PMID: 27091696. DOI: 10.1016/j.jconrel. 2016.04.018

58 Giaccone G, Zatloukal P, Roubec J, Floor K, Musil J, Kuta M, van Klaveren RJ, Chaudhary S, Gunther A and Shamsili S: Multicenter phase II trial of YM155, a small-molecule suppressor of survivin, in patients with advanced, refractory, non-small-cell lung cancer. J Clin Oncol 27(27): 4481-4486, 2009. PMID: 19687333. DOI: 10.1200/jco.2008.21.1862

59 Clemens MR, Gladkov OA, Gartner E, Vladimirov V, Crown J, Steinberg J, Jie F and Keating A: Phase II, multicenter, openlabel, randomized study of YM155 plus docetaxel as first-line treatment in patients with HER2-negative metastatic breast cancer. Breast Cancer Res Treat 149(1): 171-179, 2015. PMID: 25547219. DOI: 10.1007/s10549-014-3238-6

60 Kelly RJ, Thomas A, Rajan A, Chun G, Lopez-Chavez A, Szabo E, Spencer S, Carter CA, Guha U, Khozin S, Poondru S, Van Sant C, Keating A, Steinberg SM, Figg W and Giaccone G: A phase I/II study of sepantronium bromide (YM155, survivin suppressor) with paclitaxel and carboplatin in patients with advanced non-small-cell lung cancer. Ann Oncol 24(10): 26012606, 2013. PMID: 23857959. DOI: 10.1093/annonc/mdt249

61 Kudchadkar R, Ernst S, Chmielowski B, Redman BG, Steinberg J, Keating A, Jie F, Chen C, Gonzalez R and Weber J: A phase 2, multicenter, open-label study of sepantronium bromide (YM155) plus docetaxel in patients with stage III (unresectable) or stage IV melanoma. Cancer Med 4(5): 643-650, 2015. PMID: 25533314. DOI: $10.1002 /$ cam 4.363

62 Wiechno P, Somer BG, Mellado B, Chlosta PL, Cervera Grau JM, Castellano D, Reuter C, Stockle M, Kamradt J, Pikiel J, Duran I, Wedel S, Callies S, Andre V, Hurt K, Brown J, Lahn M and Heinrich B: A randomised phase 2 study combining LY2181308 sodium (survivin antisense oligonucleotide) with first-line docetaxel/prednisone in patients with castrationresistant prostate cancer. Eur Urol 65(3): 516-520, 2014. PMID: 24246407. DOI: $10.1016 /$ j.eururo.2013.10.039
63 Talbot DC, Ranson M, Davies J, Lahn M, Callies S, Andre V, Kadam S, Burgess M, Slapak C, Olsen AL, McHugh PJ, de Bono JS, Matthews J, Saleem A and Price P: Tumor survivin is downregulated by the antisense oligonucleotide LY2181308: a proof-of-concept, first-in-human dose study. Clin Cancer Res 16(24): 6150-6158, 2010. PMID: 21041181. DOI: 10.1158/10780432.CCR-10-1932

64 Navari RM, Qin R, Ruddy KJ, Liu H, Powell SF, Bajaj M, Dietrich L, Biggs D, Lafky JM and Loprinzi CL: Olanzapine for the prevention of chemotherapy-induced nausea and vomiting. N Engl J Med 375(2): 134-142, 2016. PMID: 27410922. DOI: 10.1056/NEJMoa1515725

65 Nelson JC, Weiller E, Zhang P, Weiss C and Hobart M: Efficacy of adjunctive brexpiprazole on the core symptoms of major depressive disorder: A post hoc analysis of two pooled clinical studies. J Affect Disord 227: 103-108, 2018. PMID: 29055257. DOI: $10.1016 /$ j.jad.2017.09.054

66 Thase ME, Youakim JM, Skuban A, Hobart M, Zhang P, McQuade RD, Nyilas M, Carson WH, Sanchez R and Eriksson $\mathrm{H}$ : Adjunctive brexpiprazole 1 and $3 \mathrm{mg}$ for patients with major depressive disorder following inadequate response to antidepressants: a phase 3, randomized, double-blind study. J Clin Psychiatry 76(9): 1232-1240, 2015. PMID: 26301771. DOI: 10.4088/JCP.14m09689
Received August 8, 2019

Revised August 14, 2019 Accepted August 15, 2019 